THE AGE OF REFORM

1250-1550 
This page intentionally left blank 


\section{The Age \\ of Reform \\ 1250-1550 \\ AN INTELLECTUAL AND \\ RELIGIOUS HISTORY OF \\ LATE MEDIEVAL AND \\ REFORMATION EUROPE}

\section{STEVEN OZMENT}

With a New Foreword by

CARLOS EIRE and

RONALD K. RITTGERS

NEW HAVEN AND LONDON

YALE UNIVERSITY PRESS 
Published with assistance from the foundation established in memory of Amasa Stone Mather of the Class of 1907 , Yale College.

Copyright $(\odot 1980$ by Yale University.

Foreword copyright (c) 2020 by Yale University.

All rights reserved. This book may not be reproduced, in whole or in part, in any form (beyond that copying permitted by Sections 107 and 108 of the U.S. Copyright Law and except by reviewers for the public press), without written permission from the publishers.

Designed by Sally Harris and set in VIP Baskerville type.

Printed in the United States of America.

ISBN: 978-o-300-20355-4（pbk.)

Library of Congress Control Number: 2020932733

10987654321 
For Heiko and Toetie 
This page intentionally left blank 